\title{
Aikuisväestön tietoteknisten valmiuksien parantaminen
}

Tiedolle rakettu. Aikuisväestön tietoteknisten valmiuksien parantaminen. Komiteanmietintö 1988:22.

Tietotekniikan neuvottelukunnalta on ilmestynyt mietintö Tiedolle rakettu. Tietotekniikka rakennemuutoksessa ja sen hallinnassa. Neuvottelukunta esittää tietopoliittisia kannanottoja ja ratkaisuehdotuksia kysymyksiin, joita tietotekniikan nopea käyttöönotto on nostanut esille. Yksi keskeinen alue on tietotekniikan hallinta ja koulutuskysymykset. Näitä asioita varten neuvottelukunnalla on ollut jaosto, jonka työn tulokset on raportoitu erillisessä osamietinnössä: Aikuisväestön tietoteknisten valmiuksien parantaminen (KM 1988:22). Jatkotyössään neuvottelukunta pitää edelleen tärkeänä aikuisten tietotekniikkakoulutuksen kysymysten käsittelyä. Se ottaa tehtäväkseen myös tietotekniikan vaikutusten hallintaan liittyvän tutkimuksen seuraamisen ja tiedon siirtämisen työelämän hyödyksi.

Tämänkin lehden lähiajan numeroissa on esitelty varsin laajasti aikuis- ja ammatillista koulutusta koskevia periaatepäätöksiä, kehittämissuunnitelmia ja mietintöjä. Ilmestynyt mietintö täydentää tätä keskustelua tietotekniikkakoulutuksen osalta. Siinä pohditaan kysymyksiä: ketä ja mitä pitäisi kouluttaa, vähemmälle jää pohdinta miten pitäisi kouluttaa.

Mietinnön lähtökohtana on seuraava ajatus:

"Kansalaisilla olisi oman etunsa vuoksi hyödyllistä olla tietotekniikan soveltamisessa sellaiset valmiudet, että jokainen voisi osallistua tarvittavassa määrin työpaikallaan tietotekniikkaan perustuvien tietojärjestelmien kehittämiseen sekä ottaa kantaa tietotekniikan käyttöön yhteiskunnassa ja hyötyä sen tuomista mahdollisuuksista".

Aikaisempia tarkasteluja tietotek- niikan ja tietokoneen välineellisen käytön osaamisesta halutaan täydentää korostamalla näkemystä siitä, miten ihmiset selviävät tietotekniikan käyttöön perustuvista työtehtävistään. Nyt tulisi tietoisesti pyrkiä järjestelmien kehittämisvalmiuksien saavuttamiseen käyttäjien piirissä. Käyttäjät voisivat näin osallistua kehittämiseen ja oppia jo ennakolta käyttämään ja edelleenkehittämään uutta järjestelmää. Vaikka nämä tavoitteet koskevat lähinnä työssäkäyvää väestöä, työroolia, on jaosto esittänyt myös koko aikuisväestöä koskevia tavoitteita eli miten tietotekniikkaa tulisi hallita kansalaisroolissa.

Mietintö esittelee varsin paljon määrällisiä toteutumatietoja ja tarvearvioita. Oppilaitostyypeittäin ja hallinnollisen muodon mukaan (henkilöstökoulutus, työllisyyskoulutus, omaehtoinen opiskelu) on tarkasteltu koulutustarjontaa ja koulutettujen määriä. Esimerkiksi vuonna 1987 tietotekniikan opetukseen osallistui 112180 henkilöä erilaisissa vapaan sivistystyön oppilaitoksissa, kesäyliopistoissa ja kaupallisten yritysten kursseilla. Tähän lukuun tulevat vielä lisäksi korkeakoulujen täydennyskoulutuskeskusten sekä yritysten ja laitosten henkilöstökoulutukseen osallistuneet, joista ei ollut lukumäärätietoja käytettävissä.

Niin tässä kuin muissakin alan mietinnöissä pidetään suhteellisen riittävinä ja tarkoituksenmukaisina niitä oppilaitostyyppejä, jotka aikuisväestöä voivat palvella. Erityisesti tietotekniikan opetus ja $\mathrm{mm}$. henkilöstökoulutuksen lisääntyminen asettavat kuitenkin näiden oppilaitosten koulutustarjonnalle ja palvelevuudelle lisääntyviä ja uusia vaatimuksia. Vaikka kurssitarjontaa on paljon, sen alueellinen saavutettavuus ei ole tasapuolista. Lisääntyvän ja valtakunnan eri osiin ulottuvan koulutuksen järjestämiseksi jaosto esittää etäopetuksen kehittämistä.

Mietinnössä on arvioitu myös, kuinka moni on kuluneen viiden vuoden aikana saavuttanut tieto- tekniikan perus- ja kehittämisvalmiudet. Luvut kuvaavat kuitenkin vain kursseille osallistumista. Selvityksiä henkilöiden todellisista tietotekniikan käyttövalmiuksista ei sen sijaan ole tehty. Perusteellisessa nykytilan kuvauksessa on tietoa koulutusmuodoittain koulutuksen sisällöstä ja kestosta sekä osallistujamääristä.

\section{Tietotekniikkavalmiuksille tavoite- tasot}

Jaosto on muodostanut koulutustarvearvioinnin tueksi tietotekniikkavalmiuksille tavoitetasot; seitsemän tasoa perusvalmiuksista kehittämistehtävien suorittamisessa tarvittaviin syvällisiin osallistumisvalmiuksiin asti. Lyhyt kuvaus on annettu siitä, mitä eri tasot merkitsevät toisaalta kansalaisten kannalta ja toisaalta työroolissa. Määrällinen tavoite eri valmiustasoilla ja eri kohderyhmissä on esitetty suhdelukuna: kuinka monta prosenttia kustakin kohderyhmästä tarvitsisi ao. valmiustason. Esimerkiksi puolet niistä, jotka työskentelevät tietointensiivisessä työssä suuressa organisaatiossa, tarvitsee syvällisen osallistumisvalmiuden eli "kykenee omaan työhönsä liittyvän tietojärjestelmän tieto- ja kehittämistarpeiden määrittelyyn sekä arvioimaan osaltaan erilaisia järjestelmän toteutumisvaihtoehtoja, sekä pystyy myös osallistumaan kehittämisestä vastuussa olevan projektiryhmän työhön oman työyksikkönsä edustajana sekä ryhmässä yhtenä sen jäsenenä hoitamaan yhteyksiä edustamaansa tahoon ja tuomaan esille sen vaatimukset tietojärjestelmälle sekä jatkuvaan yhteistyöhön tietotekniikan asiantuntijoiden kanssa". Jaoston määrällisten tavoitteiden mukaan olisi 270000 henkilön saavutettava tämä taso vuoteen 2000 mennessä.

Vaatimusten kuvaus sisältää siis muitakin kuin puhtaasti tietotekniikan hallinnan tavoitteita. Sen sijaan kuvaus ei kerro, mitä asioita pitäisi opettaa ja miten, jotta halu- 
tut valmiudet saavutetaan. Kaikkien katsotaan tarvitsevan perusvalmiudet ja yleiset käyttövalmiudet (onko näitä siis syytä erotella?). Olisiko tämä taso yleissivistykseen luettavaa ja syytä kuvata yksityiskohtaisemmin myös sen koulutuksen sisältöä: esim. mitä pitää tietää siitä tekniikasta, fysiikasta, logiikasta, jolle atk perustuu; mitä pitää tietää tiedon luonteesta ja tietojärjestelmien periaatteista ja rakenteesta? Yksi askel tähän suuntaan sisältyy mietinnön ehdotukseen: "Tietotekniikan Liitto ry:n tulisi kehittää kuvaukset tietotekniikan perus- ja käyttövalmiuksista sekä niiden saavuttamiseen edellyttävän koulutuksen sisällöstä".

\section{Toteutus henkilöstökoulutuksena}

Ehdotuksen mukaan työroolissa tarvittava koulutus tulisi toteuttaa pääosin henkilöstökoulutuksena ja niin, että tarvittaessa järjestetään valtionapua koulutukseen osallistumisen tueksi. Tähän tarkoitukseen soveltuvaa koulutusta voidaan järjestää kaikentyyppisissä oppilaitoksissa tai yritysten ja laitosten sisällä. Erikoistumista koulutuslaitoksen asiantuntemusalueen mukaan, koulutuksen sisällön mukaan tai työntekijä-/ammattiryhmittäin suositellaan kuitenkin $\mathrm{mm}$. koulutuksen laadun varmistamiseksi.

Tärkeää on liittää tietotekniikan koulutus työpaikoilla henkilöstön kehittämissuunnitelmaan ja tietojenkäsittelyn kehittämissuunnitelmaan. Jaoston ehdotukset yhteistyöstä ja vastuun paremmasta jakamisesta koulutuskysymyksissä ovat kannatettavia. Tietotekniikkakoulutuksen parempi kytkeminen työn ja järjestelmien kehittämishankkeisiin ei ole helppoa. Tämä pyrkimys asettaa uudenlaisia vaatimuksia myös koulutusta tarjoaville laitoksille, jotta niiden palveluja voitaisiin käyttää joustavasti osana koulutus-kehittämishankkeita. Työnantajilla on varmasti halua parantaa koulutuksen oikeaaikaisuutta ja vaikuttavuutta jo tuottavuuden turvaamisen takia. Osaamattomuus käy raskaaksi kaikille osapuolille, jos tukea ei riittävästi saada.

Koordinaattorin roolia on kaavailtu tietojenkäsittelyn kehittämisvastuuhenkilöille, niin atk-ammattilaisten ja käyttäjien välille kuin myös tietotekniikan käyttöönoton ja koulutuksen niveltämiseen. Täs sä mielessä mietinnössä kerrotaan varsin yksityiskohtaisesti näiden vastuuhenkilöiden koulutusohjelmasta ja tehtäväkuvasta. Samalla se on kuvaus koulutuksesta, jolla yritetään tuottaa varsin syvällisiä osallistumis- ja kehittämisvalmiuksia.

Em. koulutusohjelma on myös esimerkki opiskelusta, johon osallistuja joutuu panostamaan omaa aikaansa ja energiaansa. Henkilöstökoulutus ei kuitenkaan johda keskenään vertailukelpoisiin tai muodollista pätevyyttä lisääviin tutkintoihin, mikä voisi olla työntekijän kannalta arvokasta ajatellen myöhempiä työnhakutilanteita; pitäisi jotenkin voida osoittaa tietotekniikkaan liittyvät valmiutensa. Toisaalta koulutus osana uuden tietojärjestelmän kehittämistä voi olla motivoivaa. Nykyistä työnantajaa ja työtehtäviä palvelee paremmin kiinteästi työtehtäviin liittyvä koulutus, joka vielä ehkä toteutetaan yhdessä koko työyksikön kanssa. Samanaikaisesti tarvitaan useita aikuisväestölle soveltuvan tietotekniikkakoulutuksen kehittämisen suuntia.

\section{Omaehtoinen tietotekniikan opis- kelu}

Työssäkäyville uuden tekniikan oppimisesta aiheutuvat paineet ovat suurempia kuin kansalaisille yleensä. Samalla työelämään osallistuminen turvaa aikuiselle tietotekniikankin kohdalla suhteellisen hyvin ajan tasalla pysymisen. Mikäli organisaatio ottaa modernia tekniikkaa käyttöön, omaan työhön kuuluvien uusimpien työvälineiden käyttötaito on mahdollista säilyttää. Esimerkkejä on kuitenkin jo nyt siitä, että niissä organisaatioissa, joissa on viivytelty tietokoneaikaan siirtymisessä, työntekijätkin jäävät huonompaan asemaan yrittäessään siirtyä uuteen työhön. Tätä varten on tarpeen kehittää omaehtoisia opiskelumahdollisuuksia ja mm. kansalaisopistojen kurssitoimintaa. Kansalaisopistot voisivatkin suunnitella tietotekniikan opetustaan tavoitteellisempina kokonaisuuksina samaan tapaan kuin kielten opiskelu on järjestetty, joissain tapauksissa jopa taideaineiden opiskelu. Mietinnössä on ainakin luvattu riittävät koulutettavamäärät, jos heidät vain tavoitetaan.

Neuvottelukunnan jaosto on asettanut vastaavanlaisia tavoitetasoja tietotekniikan valmiuksille kansalaisroolissa kuin edellä on esitetty työrooliin liittyen. Aikuisten kiinnostus kohdistuu varmasti joskus myös tietotekniikkaan sinänsä, mutta hedelmällistä sattaisi olla tietokoneen käytön opetus läpäisyperiaatteella eri aiheiden opiskelun yhteydessä. Esitetyt näkemykset erilaisten kodin työasemien ja julkisten tietoverkkojen opettavasta merkityksestä vaikuttavat liian optimistisilta ajatellen koko aikuisväestön koulutustarpeita.

\section{Mikä koulutuksen sisällöksi?}

Nykyisen koulutuksen sisältöä ja laatua ei mietinnössä nähdä erityisen ongelmallisena eikä arvioida, johtavatko ne esitettyjen tavoitteiden suuntaan. Viimeinen luku sisältää ehdotuksia koulutuksen kehittämiseksi ja laadun varmistamiseksi. Opetussministeriölle osoitetaan yleinen vastuu opetussuunnitelmien ja -menetelmien kehittämisestä. Jaoston mukaan opettajakoulutus on avainasemassa: opettajien täydennyskoulutukseen tulisi kuulua mm. tietotekniikan erityisdidaktiikan vahvistaminen ja työelämän atk-sovelluksiin perehtyminen.

Tietokoneavusteisten opetusohjelmien tiellä ollaan vasta alussa. Jaostolla ei ole uusia näkemyksiä tietokoneavusteisen tai monimuoto-opetuksen merkityksestä ja toteutuksen mahdollisuuksista. Lisäksi tietotekniikan ala on niin nopeasti uudistuvaa, että oppimateriaalitilannetta, paremmin kuin opettajien koulutustakaan, ei voida hoitaa kertakaikkisena, vaan niissä tarvitaan jatkuvaa ajan tasalla pitoa, uudistamista yhdessä opetussuunnitelmien kanssa.

Mietintö on koulutuspoliittinen kannanotto siihen, mitä tulisi saavuttaa. Se sisältää joitakin kehittämisehdotuksia, mutta ei tee konkreettisia esityksiä koulutuksen sisällöstä tai tietotekniikan opetuksen didaktisesta kehittämisestä Aikuiset voivat varmaan pohtia omaa suhdettaan tietotekniikkaan opistojen yhteiskunnallisissa piireissä, työpaikoilla tätä keskustelua käydään lähes päivittäin. Koulutussuunnittelijoidenkin lasihelmipelissä on eri tasoja: miten edistää oppimista tavoitteiden suuntaan, että saavutettaisiin nykyisten työtehtävien edellyttämät valmiudet - ja sitten vähän ylittää se taso.

Pirjo Liewendahl 